\title{
Composition, species richness and patterns of nycthemeral vertical distribution of planktonic cladocereans in a black water Amazonian lake
}

André Ricardo Ghidini and Edinaldo Nelson dos Santos-Silva

Instituto Nacional de Pesquisas da Amazônia. Coordenação de Pesquisas em Biodiversidade. Av. André Araújo, 2936. CEP: 69060-001, Manaus, Amazonas, Brasil. E-mails: (ARG) andrericardo83@gmail.com, (ENSS) nelson@inpa.gov.br

\section{Abstract}

The aim of this study was to identify patterns of vertical distribution of planktonic cladocerean populations throughout the diel cycle, during the low and high water periods, and its ecological implications for a black water Amazonian lake. Tupé Lake is a black water lake located near the Brazilian city of Manaus. A channel links the lake with the Negro River and its flood pulse. This study was performed in a low-water period (November 2005) and in a high-water period (June 2006). Samples were taken on a 24-hour cycle, every 4 hours and at each meter of the water column, using a Schindler-Patalas trap equipped with a $55 \mu \mathrm{m}$ size mesh. A total of 16 species were registered during the low water period, wherein Bosminopsis deitersi, Moina minuta, and Ceriodaphnia cornuta were the most abundant species. $B$. deitersi migrated to the bottom during the afternoon, while $M$. minuta, Moina reticulata, and Holopedium amazonicum remained the bottom for the entire diel cycle. During the high-water period, a total of 18 species were observed, and B. deitersi, C. cornuta, and Diaphanosoma polyspina were the most abundant species. During both sampling periods, no pattern was detected for $C$. cornuta. Generally, vertical patterns of distribution were less evident in the high water period, due to the mixing of the lake.

Key Words: Black water lake, Central Amazon, Cladocera, Vertical migration.

\section{Introduction}

Zooplankton populations are distributed heterogeneously throughout an ecosystem and, as previously reported by Pinel-Alloul (1995), they usually exploit the environment in patches. In tropical lakes, this heterogeneity generally occurs seasonally in a spatial-temporal scale and daily in a vertical- horizontal scale. The vertical distribution of the organisms is a direct result of their vertical migration behaviors.

According to Cushing (1951), the capacity to perform vertical movements through the water column, vertical migration, was first observed in marine zooplankton by Cuvier in 1817. Even though vertical migration of zooplankton has been frequently studied in freshwater communities for the 
last two centuries (reviews e.g. Cushing, 1951; Hutchinson, 1967; Lampert, 1989; Lampert and Sommer, 1997) the real adaptive significance of the phenomenon is still not completely understood.

Zaret and Suffern (1976) explained vertical migration as a mechanism of zooplankton to avoid predation, which is related to luminosity, body size and visibility of the prey. These factors cause predators like planktivorous fish to prey differently on the Cladocera community (Zaret, 1972; Zaret and Kerfoot, 1975). Later, Lampert (1989) pointed to light-related mortality as the ultimate reason for the vertical movements.

In the Neotropical region, studies have associated vertical distribution of planktonic cladocereans with variations in temperature and, consequently, oxygen (Arcifa-Zago, 1978, Matsumura-Tundisi et al., 1984; Nogueira and Panarelli, 1997). Perticarrari etal. (2003) points to a close relationship between the populations of Bosmina tubicen and Chaoborus sp., an invertebrate predator, reporting predator-prey interactions as the main influence on vertical migration. More recently, a nocturnal vertical migration pattern was detected for cladocereans in a shallow tropical reservoir in Northeastern Brazil (Silva et al., 2009). Bezerra-Neto et al. (2009) detected the occurrence of diel vertical migration in a Brazilian reservoir with planktivorous fish and the absence of vertical movements in a fish absent situation.

There are few existing studies regarding vertical migration in the Brazilian Amazon floodplain, a location where the flood pulse of Amazon River and its tributaries promote periodic changes in all aquatic communities. In white-water lakes, Fisher et al. (1983) did not find clear evidence of vertical movements, but they discovered Daphnia gessneris preference to remain in deeper layers. The same was observed by Keppeler and Hardy (2004) for most species of the zooplankton community. Rejas et al. (2007) observed the diel vertical migration of planktonic cladocereans in a Bolivian "várzea" lake and detected a strong predator-avoidance relationship between zooplankton and Chaoborus larvae. Regarding black water lakes, Previatelli et al. (2005) detected cladocereans remaining in the deeper layers of the water for the majority of the 24hour cycle. Our purpose in this paper was to determine the diel vertical distribution of cladocereans and the uncover the composition and abundance patterns of this community in a black water Amazonian lake, comparing low and high-water periods, in order to determine possible shifts in the community and explore possible causes for these attributes.

\section{Materials and Methods}

Tupé Lake is a black water lake located in the Tupé Sustainable Development Reserve (Reserva de Desenvolvimento Sustentável Tupé), $30 \mathrm{~km}$ from Manaus, in the Brazilian State of Amazonas. The lake occupies 67 hectares, and its water volume ranges between 1.44 and 2.57 million $\mathrm{m}^{3}$ throughout the year (Aprile and Darwich, 2005). A 20m channel connects the lake with the Negro river and, as with many river-connected lakes, most hydrologic characteristic variations are related to the flood pulse of the Negro River. The lake's depth ranges from 4 to 15 meters in the central region of the lake. According to Rai and Hill (1981), the lake's trophic state shifts from dystrophic to mid-eutrophic during the course of the hydrologic cycle.

The samples were taken in the deepest region of the lake $\left(03^{\circ} 02^{\prime} 35,4^{\prime \prime} S\right.$ $60^{\circ} 15^{\prime} 17,5^{\prime} \mathrm{W}$ ) (Fig. 1), during both the low water period (lake depth $=4.5 \mathrm{~m})$ (November $11^{\text {th }}, 2005$ ) and the high water period (lake depth $=13.5 \mathrm{~m})$ (June $13^{\text {th }}, 2006$ ). Throughout the 24-hour period, sampling was performed every 4 hours. Samples were taken at every meter of the water column (from the subsurface to the bottom) using a 12-liter Schindler-Patalas trap. A total of 24 liters were collected, filtered through a plankton net with a $55 \mu \mathrm{m}$ mesh size and fixed with formalin to reach a final concentration of 6\%. Dissolved oxygen $\left(\mathrm{mgO}_{2} \mathrm{~L}^{-1}\right)$, temperature $\left({ }^{\circ} \mathrm{C}\right)$, conductivity $\left(\mu \mathrm{S} . \mathrm{cm}^{-1}\right)$ and light penetration (m) were measured using an oxymeter (YSI55 

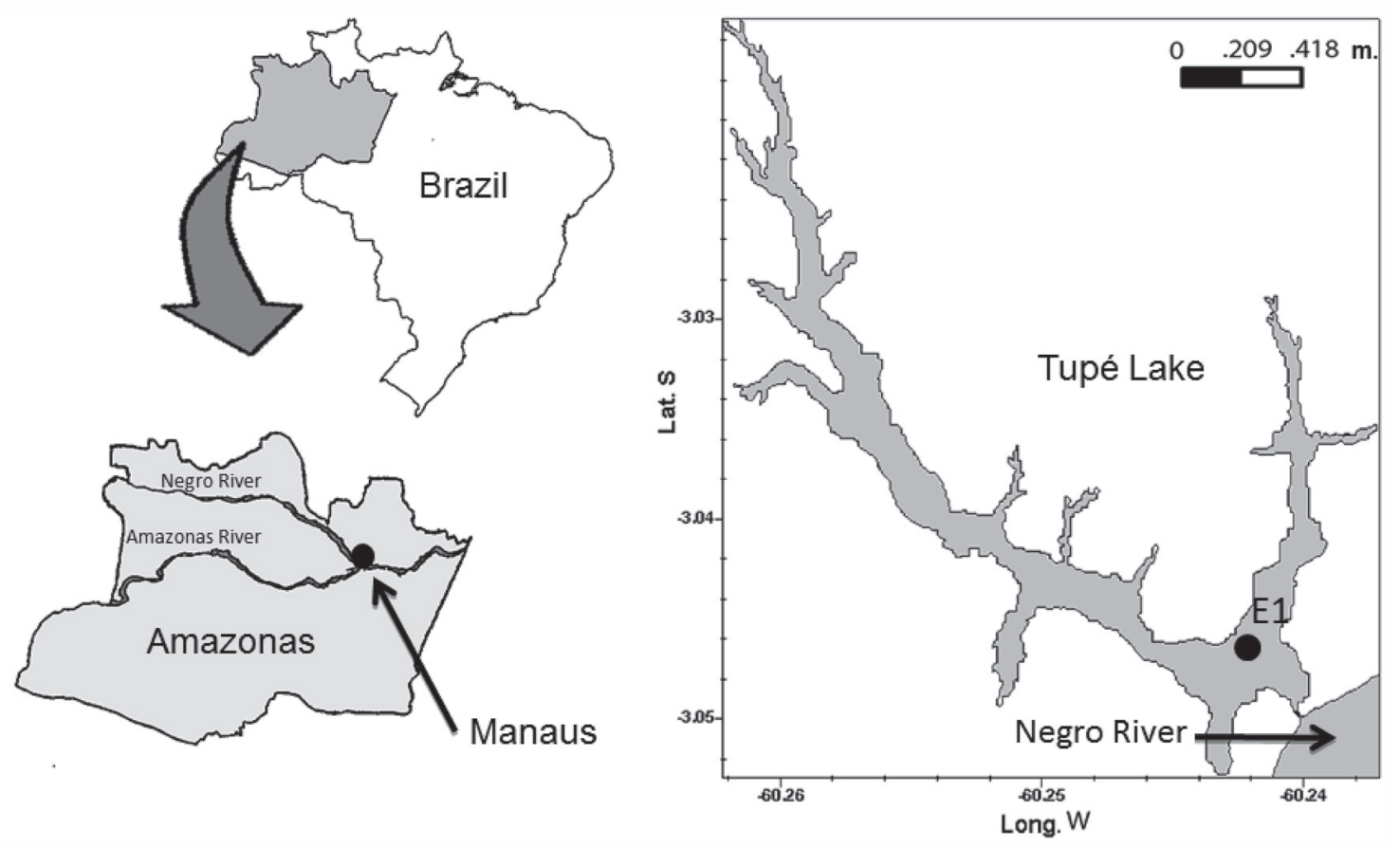

Figure 1. Location of the study area, highlighting the Amazonas State, and the "Tupé" Lake, with the position of the sampling station.

- Yellow Springs), a conductivimeter (YSI30 Yellow Springs) and a Secchi disk, respectively. The organisms were counted in a Sedgewick-Rafter chamber using an optical microscope. Final abundance was expressed as organisms per cubic meter. In order to establish a relationship between the predators in the samples, a quantification of Chaoboridae populations in the samples was made. Identification of the species was based on previous studies by Elmoor-Loureiro (1997), Smirnov (1996) and Velho et al. (2000). Correlations between physical and chemical parameters and the Cladocera species (abundance and composition) were tested with a Canonical Correspondence Analysis, while the correlation between the population densities of cladocereans and chaoboridae was made using Spearman's index. Kruskal Wallis ANOVA was performed to determine if there was a difference between the total densities of cladocereans considering both the hours of the cycle and sample depths. All analyses were made using PAST (Hammer et al., 2001). Counter plots graphs were made using Sigmaplot 10.0 (Systat, 2006).

\section{Results}

Low water period (November/2005)

The transparency of the water column, measured using a Secchi disk, was $1.2 \mathrm{~m}$. The temperature was lower in the deeper layer during most of the day $\left(27^{\circ} \mathrm{C}\right)$, with a variation of $4^{\circ} \mathrm{C}$ when compared to the surface $\left(31^{\circ} \mathrm{C}\right)$, indicating the existence of thermal stratification in the lake during this period. Regarding the electrical conductivity, it ranged from 4 to $8 \mu S . \mathrm{cm}^{-1}$; lower values were registered at the surface. Dissolved oxygen presented high vertical variation and its distribution was stratified during the entire day varying from 7 to $2 \mathrm{mgO}^{2} / \mathrm{L}$, from top to bottom (Fig. 2). Oxygen saturation was higher in the first $3 \mathrm{~m}$ of the water column (80 to $100 \%$ ) and lower in the bottom (10 to $15 \%$ ) of the water column.

A total of sixteen species of Cladocera were identified. Bosminopsis deitersi and Moina minuta were the most abundant species (around 30\% each), followed by Ceriodaphnia cornuta (20\%) and Diaphanosoma polyspina (15\%); these species represented more than $90 \%$ of the counted organisms. Chydoridae and Ilyocryptidae were registered in low 


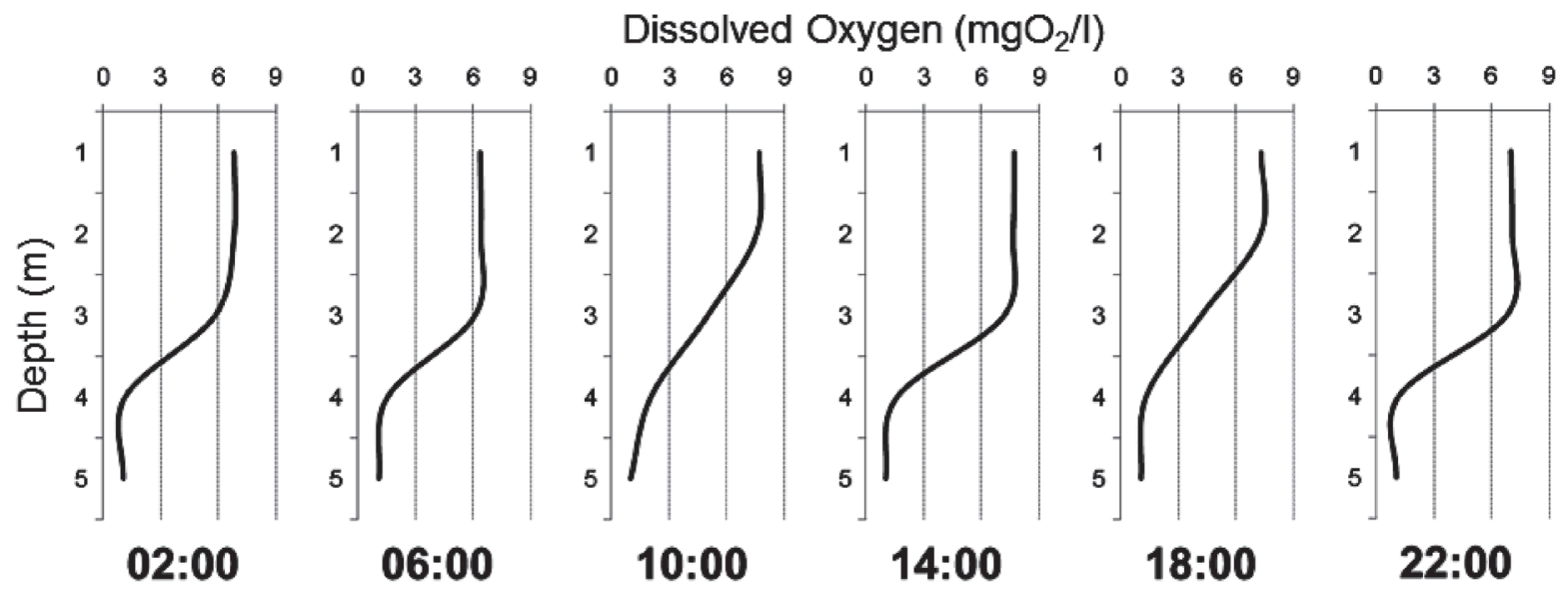

Figure 2. Variation of dissolved oxygen, during the 24-hour cycle in all depths, in Tupé lake during the low water period (November/2005).

Table 1. Cladoceran species and relative abundance, during the high and low water level periods, in Tupé Lake. NR: not registered.

\begin{tabular}{|c|c|c|}
\hline \multirow{2}{*}{ Taxa } & \multicolumn{2}{|c|}{ Abundance (\%) } \\
\hline & Low & High \\
\hline \multicolumn{3}{|l|}{ Bosminidae } \\
\hline Bosmina longirostris (O.F. Müller, 1785) & 1.10 & 1.26 \\
\hline Bosmina hagmanni Stingelin, 1904 & 0.11 & 4,25 \\
\hline Bosmina cf. huaroensis Delachaux, 1918 & 0.02 & 0,04 \\
\hline Bosmina tubicen Brehm, 1953 & 0.14 & 1.08 \\
\hline Bosminopsis deitersi Richard, 1895 & 29.21 & 59.22 \\
\hline Bosminopsis brandorffi Rey and Vasquez, 1989 & NR & 0.15 \\
\hline Bosminopsis negrensis Brandorff, 1976 & NR & 0.75 \\
\hline \multicolumn{3}{|l|}{ Daphnidae } \\
\hline Ceriodaphnia cornuta Sars, 1886 & 19.14 & 20.72 \\
\hline Ceriodaphnia cf. pulchella Sars, 1862 & 0.32 & 0.01 \\
\hline \multicolumn{3}{|l|}{ Moinidae } \\
\hline Moina minuta Hansen, 1899 & 29.81 & 0.23 \\
\hline Moina reticulata (Daday, 1905) & 1.01 & NR \\
\hline Moina rostrata McNair, 1980 & 0.11 & 0.72 \\
\hline \multicolumn{3}{|l|}{ Sididae } \\
\hline Diaphanosoma birgei Koríneck, 1981 & 0.09 & 0.08 \\
\hline Diaphanosoma polyspina Korovchinsky, 1982 & 14.30 & 11.42 \\
\hline \multicolumn{3}{|l|}{ Ilyocryptidae } \\
\hline Ilyocryptus spinifer Herrick, 1882 & 0.07 & 0.02 \\
\hline \multicolumn{3}{|l|}{ Chydoridae } \\
\hline Alonella dadayi Birge, 1910 & 0.05 & 0.01 \\
\hline Nicsmirnovius incredibilis Daday, 1905 & 3.22 & 0.01 \\
\hline Kurzia latissima (Kurz, 1874) & NR & 0.01 \\
\hline \multicolumn{3}{|l|}{ Holopedidae } \\
\hline Holopedium amazonicum Stingelin, 1904 & 1.30 & 0.02 \\
\hline
\end{tabular}



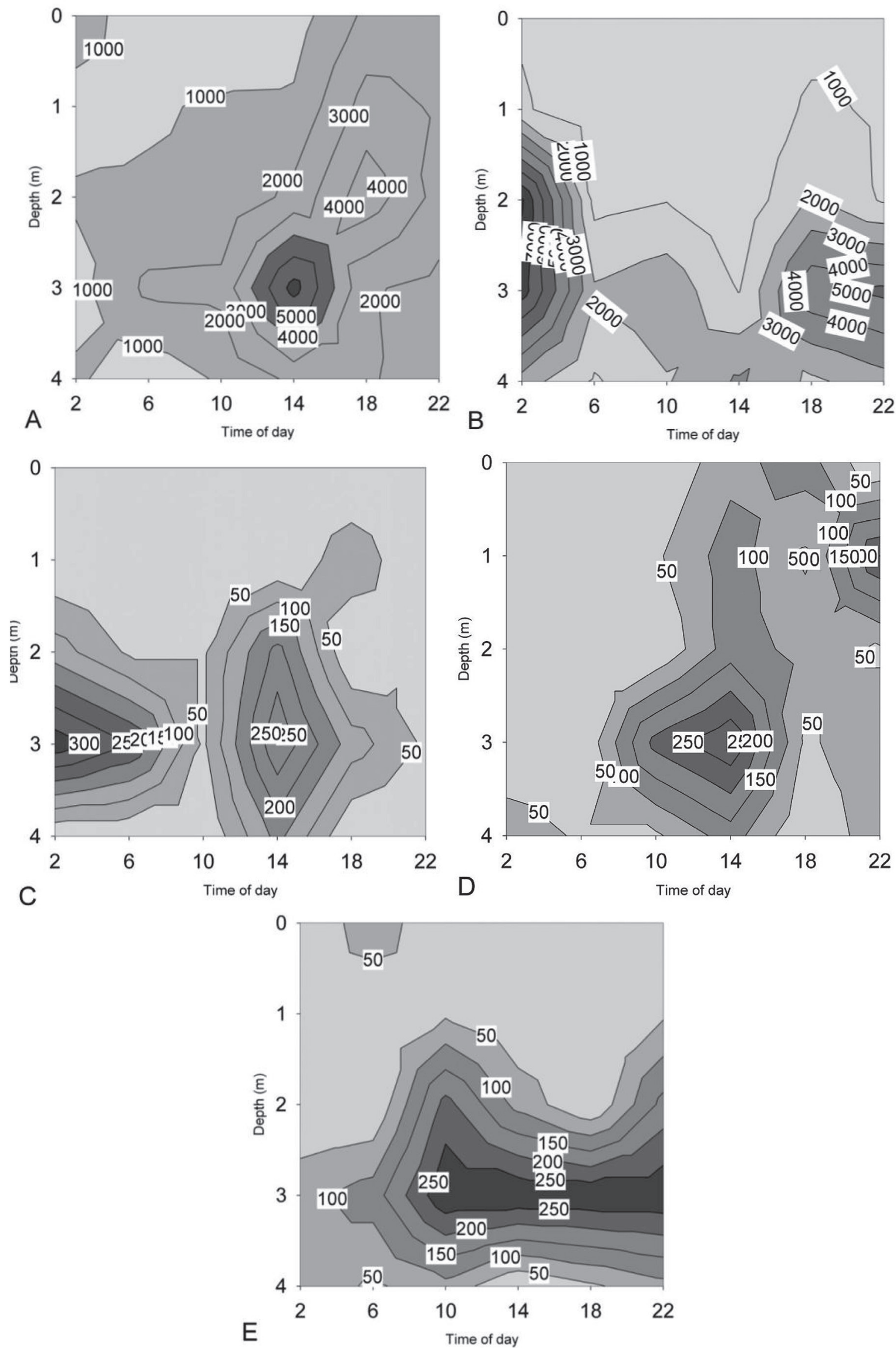

Figure 3. Vertical distribution of B. deitersi (a), M.minuta (b), M. reticulata(c), B. longiostris (d), and H. amazonicum (e) during the low water period, in Tupé Lake (november/05). The number represents aproximate density of organisms $/ \mathrm{m}^{-3}$. 
abundances (Tab. 1).

Significant differences were observed in the total vertical density of cladocereans. (Kruskal-Wallis test: $\mathrm{H}(4, \mathrm{~N}=30)=15,02366$; $\mathrm{p}=0,0047)$. Mean density of cladocereans in the low water period was $6141 \mathrm{org} / \mathrm{m}^{3}$, but great heterogeneity was observed among the samples. The density of organisms was higher at 2:00 am $\left(\right.$ mean $\left.=15816 \mathrm{org} / \mathrm{m}^{3}\right)$ and at $3 \mathrm{~m}$ deep $\left(\right.$ mean $\left.=11591 \mathrm{org} / \mathrm{m}^{3}\right)$. The lowest mean densities were observed at the surface (1974 $\mathrm{org} / \mathrm{m}^{3}$ ) and in the samples taken during the daytime (at 6:00 am $=2178 \mathrm{org} / \mathrm{m}^{3}$, at 10:00 am $\left.=2970 \mathrm{org} / \mathrm{m}^{3}\right)$. When comparing the different hours of the cycle, no statistical difference was observed (Kruskal-Wallis test: $\mathrm{H}(5, \mathrm{~N}=30)=9,366452 ; \mathrm{p}=, 0953)$.

In the low-water period, $M$. minuta, $M$. reticulata, and $H$. amazonicum remained in the deep layers of the water column, while $B$. deitersi migrated from the surface to the bottom during the afternoon and Bosminopsis longirostris showed a typical nocturnal migration pattern from the bottom to the surface (Fig. 3).

A high abundance of $B$. deitersi (Fig. 3a) during the low water period was observed mainly in the deeper layers of the water column, particularly during the afternoon $(2: 00 \mathrm{pm})$, when a peak of organisms was registered.

The vertical distribution of $M$. minuta (Fig. 3b) was quite peculiar, since higher densities were registered at 2:00 am, at depths around 3 and $4 \mathrm{~m}$, followed by an intense decrease at 6:00 am. The preference of this species for layers close to the bottom of the lake was evident. The same was found for $M$. reticulata (Fig. 3c), save any intense decrease.

Bosmina longirostris (Fig. 3d) was the only species with a peak of organisms at the surface of the water column. This peak occurred at night; during the day, the organisms remained in deeper layers. On the other hand, $H$. amazonicum was registered only in deep waters, specifically at 3 meters (Fig. 3e).

The total number of Chaoborus sp. found in the samples was similar to the densities of cladocereans. Their distribution patterns were very similar (correlation index
- Spearman, D = 0,6067; total cladocereans densities and total Chaoborus densities, log transformed), and there was a pronounced decrease of both Cladocera and Chaoborus sp. observed during the daytime (Fig. 4).

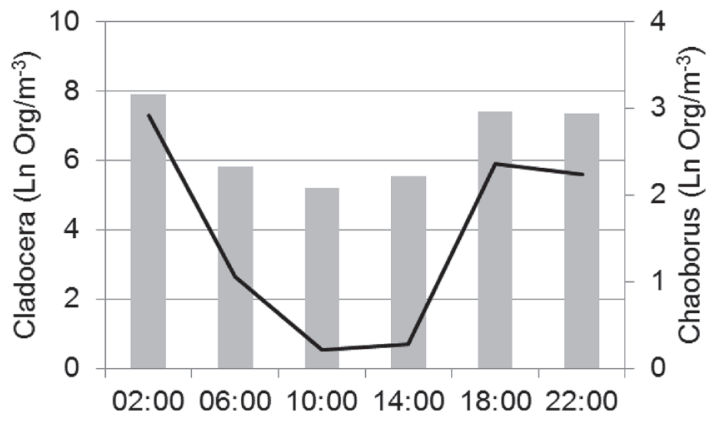

Figure 4. Mean density of cladocerans (in the left, represented by bars) and Chaoborus sp. (on the right, represent by a black line), on $\mathrm{org} / \mathrm{m}^{-3}$, during the low water period, on Tupé lake.

The relationship between the species densities of Cladocera and the physical and chemical parameters measured during the 24-hour cycle at differing depths was not determined, even after log transformation. Oxygen saturation was not used in the analysis, because it was correlated with dissolved oxygen. The Canonical Correspondence Analysis registered very low eigenvalues for species and environmental data (around 25\% of cumulative variance in both axis), and also showed low correlation between the species and environment variables (all $r<0.40$ ) with an exception for electrical conductivity ( $\mathrm{r}$ $=0.59)$. The randomization test results for Species-Environment correlation (Monte Carlo test) showed no significant correlation $(\mathrm{p}=0.1872)$.

\section{High water period (June 2006)}

During the high water period, it was not possible to observe a clear pattern of vertical variation for the abiotic parameters measured. Temperature varied from 27.0 to $28.5^{\circ} \mathrm{C}$, and higher values were registered at the surface at 10:00 am. Lower values were measured at the bottom, during the night and the early morning. Conductivity ranged from 9.5 to $11.5 \mu \mathrm{S} . \mathrm{cm}^{-1}$, with the highest values registered at 2:00 pm between 2 and 5 meters. During the early morning hours, conductivity 
Dissolved Oxygen $\left(\mathrm{mgO}_{2} / \mathrm{l}\right)$
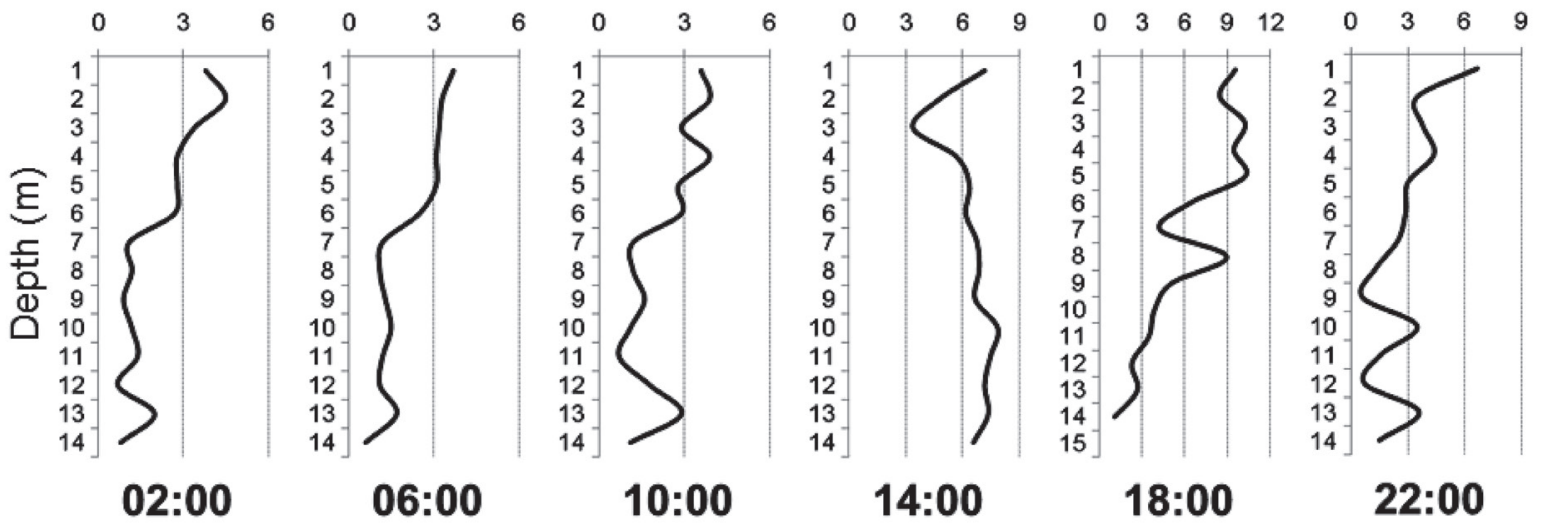

Figure 5. Variation of the dissolved oxygen, during the 24-hour cycle in all depths, in Tupé lake during the high water period (June/2006).
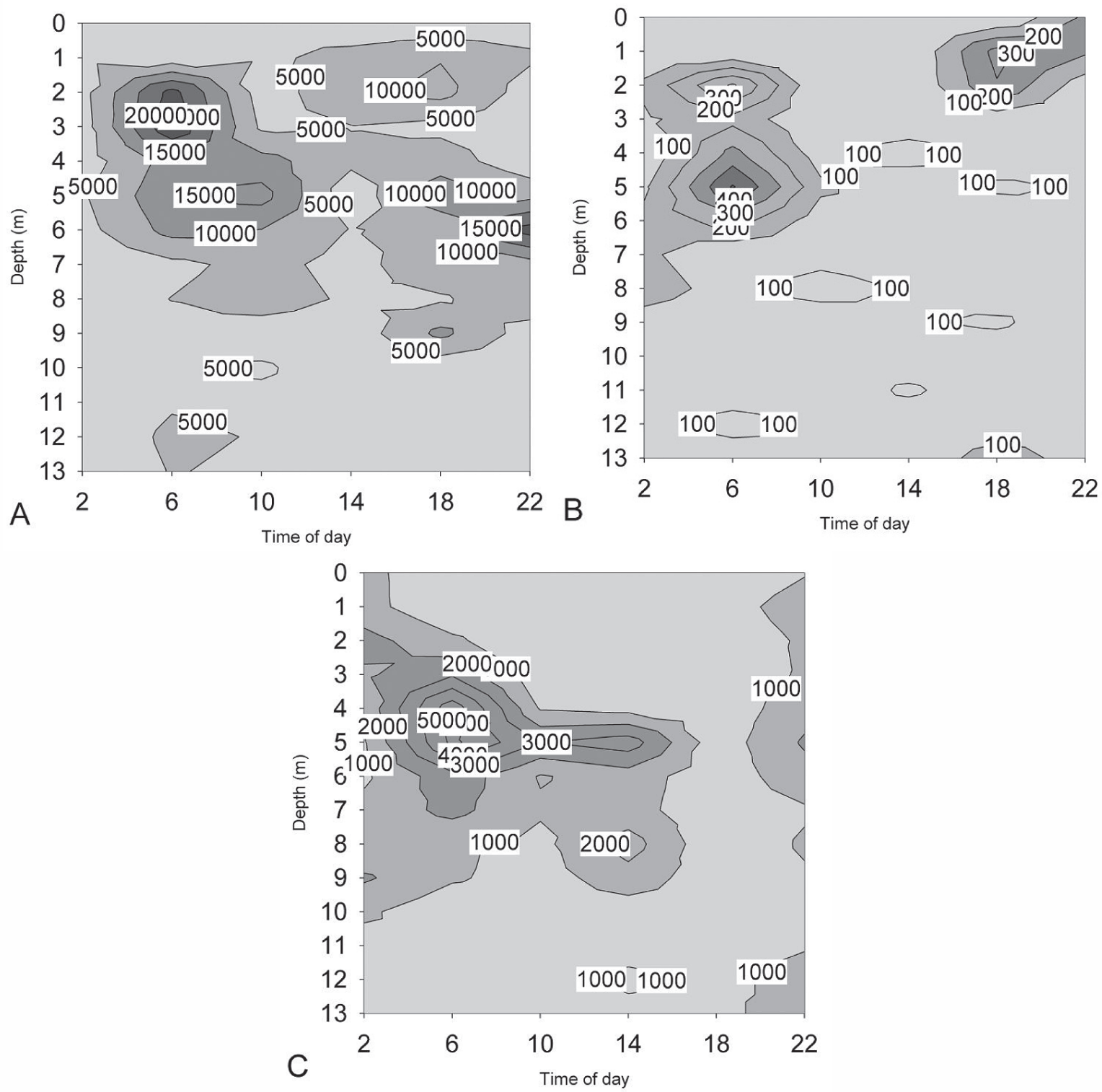

Figure 6. Vertical distribution of B. deitersi (a), B. negrensis (b) and D. polyspina (c) during the high water period, in Tupé Lake. 
values were homogeneous in the water column. Furthermore, the early morning hours between 2:00 and 6:00 am registered lower values of dissolved oxygen, from $6 \mathrm{~m}$ down to the bottom. In the following hours, the values ranged from 2 to $10 \mathrm{mgO}_{2} / \mathrm{L}$, without any clear vertical pattern, and at 2:00 pm, a value of $6 \mathrm{mgO}^{2} / \mathrm{L}$ was found in the entire water column (Fig. 5). Oxygen saturation was higher at 2:00 $\mathrm{pm}$ and 6:00 pm, ranging between $80 \%$ and $120 \%$, whereas the lowest values were recorded at the bottom, during the night/ early morning.

A total of 18 species were registered during this period. Bosminopsis negrensis and Bosminopsis brandorffi were registered exclusively during this period. There was a small increase in the population densities of Moina rostrata and Bosmina hagmanni. Bosminopsis deitersi was the most abundant species, accounting for almost $60 \%$ of the counted individuals, followed by $C$. cornuta, D. polyspina, and B. hagmanni (Tab. 1).

The mean density of cladocereans in the high water period was $9045 \mathrm{org} / \mathrm{m}^{3}$, but a great heterogeneity was observed among the samples. No significant variation in the community densities was registered within the nycthemeral cycle at the high water period between the different depths (Kruskal-Wallis test: $\mathrm{H}(13, \mathrm{~N}=84)=3,74727 ; \mathrm{p}=0,1311)$ and hours of the day (Kruskal-Wallis test: $\mathrm{H}$ $(5, \mathrm{~N}=84)=7,211148 ; \mathrm{p}=0,2054)$. Mean population densities were higher at 6:00 am $\left(=14894 \mathrm{org} / \mathrm{m}^{3}\right)$; little variation was observed during the other times of day, when mean densities ranged from 7000 to $8000 \mathrm{org} / \mathrm{m}^{3}$. When considering vertical distribution, the highest cladocerean densities were observed between 2 and 6 meters deep (maximum of $17336 \mathrm{org} / \mathrm{m}^{3}$ at 5 meters deep) when compared to other layers. Under $6 \mathrm{~m}$ deep, densities ranged between 5000 and 9000 org/ $\mathrm{m}^{3}$.

During this period, few species showed patterns of vertical distribution. High population densities of $B$. deitersi were observed during all times and all depths, with a peak of organisms observed closer to the surface at
6:00 am (Fig. 6a), indicating a possible reverse in migration movement.

Bosminopsis negrensis reached its peak in the deeper layers during the early morning and migrated to the surface at 6:00 pm (Fig. 6b). It is important to note that although this species was registered in low densities, the distribution pattern was strong. A similar pattern to the one registered for $H$. amazonicum during the low water period was observed for $D$. polyspina in the high water period, when higher densities were observed between 3 and 6 meters during most of the day (Fig. 6c). This species presented a heterogeneous distribution only during the high water period. No clear pattern of distribution was detected in the populations of $C$. cornuta and B. hagmanni during the high water period.

The Canonical Correspondence Analysis registered very low eigenvalues for species and environmental data (around 13\% of cumulative variance in both axis), and also showed low correlation between the species and environment variables (all $\mathrm{r}<0.44$ ). The randomization test results for SpeciesEnvironment correlation (Monte Carlo test) showed no significant correlation $(\mathrm{p}=0.0621)$.

\section{Discussion}

Seasonal differences in species richness and abundance

Bosminidae was the most representative family, both in terms of species richness and abundance. Bosminopsis negrensis and $B$. brandorffi were registered only during the high water period and both species are considered to be endemic to the Amazon basin (Brandorff, 1976; Rey and Vasquez, 1986).

Numerically, the species richness was similar in both periods of sampling, but there were differences in species composition, particularly when considering the species that occurred only during a specific period of the hydrological cycle. Seasonal changes in the composition of the Cladocera community during a determined cycle or hydrological period have been previously registered in 
tropical environments (Robertson and Hardy, 1984; Lansac-Tôha et al., 2004).

During the low water period, $B$. deitersi and $M$. minuta co-dominated the Cladocera community, with very similar relative abundances. $B$. deitersi and $M$. minuta are known to be found in lakes, rivers, and ponds, as these species can respond quickly to changes in the environment (Paggi and José de Paggi, 1990; Melão and Rocha, 2006). C. cornuta also occurred in both periods in very high densities.

Thus far, the records of $M$. rostrata, and $H$. amazonicum have been restricted to the Amazon Basin (Elmoor-Loureiro, 1997). Holopedium amazonicum has a large body size, and the occurrence of this species in different lakes of the Amazon basin has varied from dominant to rare, particularly in acidic waters with low suspended material (Rowe, 2000). Moina rostrata has also been associated with black water lakes (McNair, 1980).

The low abundance of Chydoridae and Ilyocryptidae species was expected, since sampling did not include the littoral region of the lake, the preferred habitat of these organisms (Whitesite et al., 1978; Smirnov, 1996). The exception, Nicsmirnovius incredibilis, is a chydorid adapted to environments with little current water and lentic systems, such as Tupé, during its low-water period (Kotov, 2003).

The differences in the population densities and species richness between the two studied periods could be related to modifications to various lake characteristics that happen naturally during the hydrological cycle. At the beginning of the flooding, the water volume increases due to the entrance of the Negro river and the increase in the flow of the lake's affluents (Aprile and Darwich, 2005).

Higher densities of Cladocera were expected during the low water period, when the lake is not connected to the Negro River. The low wind effect caused a stratification of the water column, as demonstrated by the physical and chemical parameters measured in this study. On the contrary, such a fact was not observed; the mean population densities were higher in the high water period.

Previously, studies on the zooplankton community (including cladocereans) detected lower population densities at the high water period. Hamilton et al. (1990) detected a decrease in zooplankton densities in lakes located in the Orinoco River's floodplain during the high water period; a possible consequence of this increased water volume is a dilution effect. This conclusion was also found by Brandorff and Andrade (1978) in Jacaretinga Lake. A dilution effect, however, was not detected in this study.

Carvalho (1983), studied a "várzea” lake and registered higher densities of Copepoda and Rotifera during the low water period; however, cladocereans did not demonstrate this pattern. Detritivourous species occurred during the low water period, whereas planktivourous dominated during high water periods. The same study, taking into account the entire Cladocera community, found that the differences throughout the whole year were not as pronounced for the individual Copepoda and Rotifera communities.

Comparing both periods, certain species, like $B$. deitersi and $C$. cornuta, were ever frequent. Some species occurred only in one period, like $N$. incredibilis, $H$. amazonicum, $M$. minuta and $M$. reticulata, which frequently registered in the low water period; $D$. polyspina, $M$. rostrata and $B$. negrensis registered mainly in the high water period.

\section{Patterns of vertical distribution}

Generally, patterns of vertical distribution in Cladocereans species were more commonly observed during the low water period, which could be associated to the stratified state of the lake, as observed in this study. Nogueira and Panarelli (1997) reported that the physical instability of the water column influenced the vertical distribution of zooplankton, and that stratified water bodies, with more stability and less inflow of water could facilitate the vertical movements of these organisms.

The physical and chemical parameters presented a similar variation when compared 
to a previous study performed in the lake, in which the higher amplitude of variation of the dissolved oxygen, temperature, and conductivity was detected during the low water level period (Darwich et al., 2005). In the present study, a difference $4^{\circ} \mathrm{C}$ was detected in the temperature between the surface and the bottom. This difference could constitute a physical barrier for the organism's distribution, as reported by Arcifa-Zago (1978).

Otherwise, Cladocera's species densities were high in the deeper layers when the dissolved oxygen concentration was low. The lowest levels of dissolved oxygen registered for the low water period $\left(=2 \mathrm{mgO}_{2} / \mathrm{L}\right)$ did not seem to be a limiting factor for the organisms. This last statement was also found by LansacTôha et al. (1995) when it was detected that despite the understanding that Cladocerean densities are related more to oxygenate layers, this element was abundant in the entire system.

The organism's densities were higher in deeper layers of the water column, but some species showed a preference to the surface layers, specifically $B$. longirostris during the low water period and $B$. negrensis during the high water period, both of them performing a diel vertical migration to the surface at night. This distribution pattern of $B$. longirostris was also reported by Ramos-Jiliberto et al. (2004) in a Chilean lake, but they also found the reverse movement of this species during a certain period of the year.

Many Cladocera species feed on detritus and bacteria when they are more abundant than phytoplankton; this information is particularly pertinent to this study, because most of the organisms remained at the bottom where phytoplankton densities are not typically high (Gliwicz, 1969a, b; Monakov, 1972). In this sense, higher values of conductivity were registered at the bottom, which explains the high correlation detected in the Canonical Correspondence Analysis. The correlation could be simply numerical, since conductivity expresses the concentration of ions dissolved in the water, and it has never been directly related to Cladocera. It is known that conductivity is mainly related to decomposition and productivity, as both processes promote the liberation of ions to the environment, making them available to other biological processes (Wetzel, 1983). Higher conductivity at the bottom could be related to a higher abundance of species like $B$. longirostris and $B$. deitersi, since both have detritivorous habitats (Paggi, 1979; Kotov, 1997).

The distribution of $M$. minuta was peculiar, as the densities at bottom were very high at night, and then sharply decreased in the early morning, returning to its maximum only at the end of the day. A similar pattern was observed with Chaoboridae.

In this study, both Cladocera and Chaoborus sp. were very abundant during the night at the bottom and demonstrated a sharp decrease in the early morning. If we consider that Chaoborus sp. usually preys during night, it is possible to associate the decrease of Cladocera, specifically of $M$. minuta, to Chaoborus sp. predation (deBernardi et al., 1987; Rejas et al., 2007). It is also important to associate the decrease of Chaoborus sp. densities in the early morning to the burrowing behavior of this larva, which remains in the mud throughout the day (Gosselin and Hare, 2003).

The Diptera larvae, Chaoborus sp., is an important zooplankton predator, but luminosity does not play a very important role in this case, as these organisms respond to a prey at a distance of 2 to $4 \mathrm{~mm}$. The relationship between these two groups of organisms is more related to chemical receptors and the developmental stage of the larvae than to light itself (Neill, 1981; Tollrian and Dodson, 1999; Monakov, 2003). In this study, the decrease in $M$. minuta's populations could be a consequence of intense invertebrate predation. In Tupé Lake, fish predation has already been previously observed (Previattelli and Santos-Silva, 2011).

Also, it is necessary to consider that the intense changes in population densities registered for some species in this study could be also related to horizontal migration, since this study only sampled a single area of the lake. Migration to the littoral zone or to other parts of the lake is frequently associated with 
predator avoidance, and to the search for a better food supply (Lauridsen and Buenki, 1996). Ghidini (2011) detected most of the planktonic cladocereans species of this study on the littoral zone of Tupé Lake.

Some species, like $H$. amazonicum, remain at certain layers of the water column, whose densities in the low water period were higher at 3 and 4 meters of depth. On the other hand, higher densities of $D$. polyspina were observed around $5 \mathrm{~m}$ during the high water period. $H$. amazonicum's pattern of vertical distribution was previously observed by Previatelli et al. (2005). According to DeMeester and Weider (1999), some zooplankton species have a depth selection behavior, constantly migrating in order to remain in the same layer of the water column and fit into the lake's stratification (light, temperature, food or predation pressure could also be related). This could be associated to the vertical distribution pattern registered for $H$. amazonicum, D. polyspina.

When considering the distribution of $B$. longisrostris, B. deitersi, $M$. minuta and $M$. reticulata it was possible to detect a vertical migration pattern, since these species switched their density per depth throughout the diel cycle. Broadly, the patterns of distribution of $B$. longisrostris and $B$. deitersi could be related to electrical conductivity (related to decomposition and these species' detritivorous habits), while $M$. minuta was influenced more by Chaoboridae.

The absence of a correlation between the distribution of Cladocera and the physical and chemical parameters is a frequently observed result in natural systems. Usually, more than a few factors influence the organism's composition and distribution (Lampert and Sommer, 1997; Sterza et al., 2002).

This study demonstrated that the distribution of organisms was not homogeneous and that there were many factors influencing the distribution. This finding could improve the data currently available about zooplankton communities of the Amazon Basin. Also, the fact that many species distribute themselves heterogeneously through the diel cycle and varying depths illustrates that sampling restricted to only one period of the day or only at surface level is not suitable for a true characterization of the composition and abundance of the Cladoceran community.

This final statement is extremely important, particularly when we reflect on previous studies conducted in Brazil and other countries, in which sampling was typically conducted only during the morning and only at a few different depths. This study shows that to properly evaluate the diversity and abundance of the cladocerean's planktonic community, one must sample the entire water column at least twice daily, during the morning and at night. It is also important to sample other regions of the lake to determine the role of horizontal migration in this process, consider the littoral cladocereans and monitor a higher number of environmental parameters in order to establish better relationships within the Cladocera community.

\section{Conclusions}

There was a difference in the composition of planktonic cladocereans between the low and high water periods. M. minuta, $M$. reticulata, and $H$. amazonicum occurred only/ mainly in the low water period, whereas $B$. brandorff and $B$. negrensis occurred only in the high water period. $B$. deitersi and $C$. cornuta were the most abundant species throughout the entire study. During the low water period, $B$. deitersi migrated to the bottom of the lake in the afternoon. B. longirostris showed nocturnal migration to the surface. Most individuals of M. minuta, $M$. reticulata, and $H$. amazonicum remained at the bottom at all times. During the high water period, the vertical patterns of distribution were less evident than during the low water period, with $B$. deitersi migrating to the surface during the early morning and $B$. negrensis during the early afternoon. Most cladocereans remained between 2 and 6 meters of dept. Patterns of vertical distributon by $B$ longirostris and $B$. deitersi were related to electrical conductivity, whereas the distribution 
of $M$. minuta was influenced by invertebrate predation. It became evident that to effectively sample the cladocereans in the community, the vertical distribution of its members must be considered. Sampling should be, as a rule, at least performed during the day and at night and should include the entire water column.

\section{Acknowledgements}

We thank Dr. Gerd Oltman Brandorff and Dr. Barbara Ann Robertson for their considerations and suggestions, all the students of Plankton's Lab for support during sampling and data analysis and $\mathrm{CNPq}$ for investing in the Biotupé Project and the students' scholarship.

\section{References}

Aprile, F.M. and Darwich, A.J. 2005. Modelos geomorfológicos para o lago Tupé. p. 3-18. In: Santos-Silva, E.N.; Aprile, F.M.; Scudeller, V.V. and Melo, S. (eds), Biotupé: meio físico, diversidade biológica e sóciocultural do baixo Rio Negro, Amazônia Central. Manaus: Editora INPA.

Arcifa-Zago, M.S. 1978. Vertical migration of Daphnia gessneri Herbst, 1967, in Americana Reservoir, state of São Paulo, Brazil. Verhandlungen des Internationalen Verein Limnologie, 20: 1720-1726.

Bezerra-Neto, J.F.; Melo, N.A.S.T.; MaiaBarbosa, P.M. and Pinto-Coelho, R.M. 2009. The role of predation in the diel vertical migration of zooplankton in two tropical freshwater ecosystems. Acta Limnologica Brasiliensia, 21(1): 45-56.

Brandorff, G.O. 1976. A new species of Bosminopsis (Crustacea, Cladocera) from the Rio Negro. Acta Amazonica, 6(1): 109114.

Brandorff, G.O. and Andrade, E.R. 1978. The relationship between the water level of the Amazon River and the fate of the zooplankton population in lago Jacaretinga. a várzea lake in the Central Amazon. Studies on Neotropical Fauna and Environment, 13: 63-70.

Carvalho, M.L. 1983. Efeitos da flutuação do nível da água sobre a densidade e composição do zooplâncton em um lago de várzea da Amazônia, Brasil. Acta Amazonica, 13(5-6): 715-724.

Cushing, D.H. 1951. The vertical migration of planktonic crustacea. Biological Review of the Cambridge Philosophical Society, 26: 158-192.

Darwich, A.J.; Aprile, F.M. and Robertson, B.A. 2005. Variáveis limnológicas: contribuição ao estudo espaço-temporal de águas pretas amazônicas. p. 19-34. In: Santos-Silva, E.N.; Aprile, F.M.; Scudeller, V.V. and Melo, S. (eds), Biotupé: meio físico, diversidade biológica e sócio-cultural do baixo Rio Negro, Amazônia Central. Manaus: Editora INPA.

DeBernardi, R.; Giussani, G. and Manca, M. 1987. Cladocera: predators and prey. Hydrobiologia, 145: 225-243.

Demeester, L. and Weider, L.J. 1999. Depth selection behavior: fish kairomones, and the life histories of Daphnia hyaline x galeata hybrid clones. Limnology and Oceanography, 44(5): 1248-1258.

Elmoor-Loureiro, L.M.A. 1997. Manual de Identificação de Cladóceros Límnicos do Brasil. Brasília, Universa, 156 p.

Fisher, T.R.; Melack, J.M.; Robertson, B.; Hardy, E.R. and Alves, L.F. 1983. Vertical distribution of zooplankton and physicochemical conditions during a 24-hour period in an Amazon floodplain lake Lago Calado, Brazil. Acta Amazonica, 13(34): 475-487.

Gliwic, Z.M. 1969a. The share of Algae, Bacteria and Trypton in the food of the pelagic zooplankton of Lakes with various trophic characteristics. Bulletin de l'acadêmie polonaise des sciences, 17(3): 159-165.

Gliwicz, Z.M. 1969b. Studies on the feeding of pelagic zooplankton in lakes with varying trophy. Ekologia Polska, 17(36): 663-706.

Gosselin, A. and Hare, L. 2003. Burrowing behaviour of Chaoborus flavicans larvae and its ecological significance. Journal of the 
North American Benthological Society, 22(4): 575-581.

Hamilton, S.K.; Sippel, S.J.; Lewis, W.M. Jr and Saunders, J.F.I. 1990. Zooplankton abundance and evidence for its reduction by macrophyte mats in two Orinoco floodplain lakes. Journal of Plankton Research, 12(2): 345-363.

Hollwedel, W.; Kotov, A. A. and Brandorff, G.O. 2003. Cladocera (Crustacea: Branchiopoda) from the Pantanal, Brazil. Arthropoda Selecta, 12(2): 67-93.

Hutchinson, G.E. 1967. A treatise on limnology, 2: Introduction to lake biology and the limnoplankton. New York, John Wiley and Sons, 1115 p.

Keppeller, E.C. and Hardy, E.R. 2004. Vertical distribution of zooplankton in the water column of Lago Amapá, Rio Branco, Acre, Brazil. Revista Brasileira de Zoologia, 21(2): 169-177.

Lampert, W. 1989. Essay Review: The adaptative significance of diel vertical migration of zooplankton. Functional Ecology, 3: 21-27.

Lampert, W. and Sommer, U. 1997. Limnoecology: the ecology of lakes and streams. New York, Oxford University Press, $400 \mathrm{p}$.

Lansac-Tôha, F.A.; Thomaz, S.M.; Lima, A.F.; Roberto, M.D.C. and Garcia, A.P.P. 1995. Vertical distribution of some planktonic crustaceans in a "Várzea" lake (Lake Pousada das Garças) of the floodplain of High River Paraná, MS, Brazil. International Journal of Ecology and Environmental Sciences, 21: 6778.

Lansac-Tôha, F.A.; Bonecker, C.C. and Velho, L.F.M. 2004. Composition, Species richness and abundance of the zooplankton community. p. 145-190. In: Thomaz, S.M.; Agostinho, A.A. and Hahn, N.S. (eds), The upper Paraná River and its floodplain: physical aspects, ecology and conservation. Leiden, Blackhuys Publishers.

Lauridsen, T.L. and Buenki, I. 1996. Diel changes in the horizontal distribution of zooplankton in the littoral zone of two shallow eutrophic lakes. Archives of
Hydrobiology, 137(2): 161-176.

Matsumura-Tundisi, T.; Tundisi, J.G. and Tavares, L.S. 1984. Diel migration and vertical distribution of Cladocera in Lake D. Helvecio (Minas Gerais, Brazil). Hydrobiologia, 113: 299-306.

McNair. J.N. 1980. Moina rostrata: a new species of Moinidae (Cladocera). Natulae naturae, 457: 1-6.

Meláo, M.G.G. and Rocha, O. 2006. Life history, population dynamics, standing biomass and production of Bosminopsis deitersi (Cladocera) in a shallow tropical reservoir. Acta Limnologica Brasiliensia, 18(4): 433-450.

Monakov, A.V. 1972. Review of studies on feeding of aquatic invertebrates conducted at the Institute of Biology of Inland Waters, Academy of Science, USSR. Journal of the Fisheries Research Board of Canada, 29: 363383.

Monakov, A.V. 2003. Feeding of Freshwater Invertebrates. Ghent, Kenobi Productions, $335 \mathrm{p}$.

Neill, W.E. 1981. Impact of Chaoborus predation upon the structure and dynamics of a crustacean zooplankton community. Oecologia, 48: 164-177.

Nogueira, M.G. and Panarelli, E. 1997. Estudo da migração vertical das populaçóes zooplanctônicas na represa de Jurumirim (Rio Paranapanema - São Paulo, Brasil). Acta Limnologica Brasiliensia, 9: 55-81.

Paggi, J.C. and José de Paggi, S. 1990. Zooplâncton de ambientes lóticos e lênticos do Rio Paraná médio. Acta Limnologica Brasiliensia, 3: 685-719.

Perticarrari, A.; Arcifa, M.S. and Rodrigues, R.A. 2003. Diel vertical migration of cladocerans in a tropical lake. Nauplius, 11(1): 15-25.

Pinel-Alloul, B. 1995. Spatial heterogeneity as a multiscale characteristic of zooplankton community. Hydrobiologia, 300/301: 1742.

Previatelli, D.; Santos-Silva, E.N. and Darwich, A.J. 2005. Distribuição vertical do zooplâncton e sua relação com as variáveis ambientais. p. 109-121. In: 
Santos-Silva, E.N.; Aprile, F.M.; Scudeller, V.V. and Melo, S. (eds), Biotupé: meio físico, diversidade biológica e sócio-cultural do baixo Rio Negro, Amazonas, Brasil. Manaus: Editora INPA.

Rai, H.; Hill, G. 1981. Physical and chemical studies o Lago Tupé; a Central Amazonian black water "Ria Lake". Internationale Revne ges Hydrobiologia, 66(1): 37-82.

Ramos-Jiliberto, R.; Carvajal, J.L.; Carter, M. and Zúniga, L.R. 2004. Diel vertical migration patterns of three zooplankton populations in an Chilean lake. Revista Chilena de Historia Natural, 77: 29-41.

Rejas, D; Meester, L.; Ferrufino, L; Maldonado, M. and Ollevier, F. 2007. Diel vertical migration of zooplankton in an Amazonian várzea Lake (Laguna Bufeos, Bolivia). Studies on Neotropical Fauna and Environment, 42(1): 71-81.

Rey, J. and Vasquez, E. 1989. Bosminopsis brandorffi n. sp. (Crustacea, Cladocera) une novelle espéce de Bosminidae des systémes Amazone et Orénoque. Anales de Limnologie, 25(3): 215-218.

Robertson, B.A. and Hardy, E.R. 1984. Zooplankton of Amazonia lakes and rivers. p. 337-352. In: Sioli, H. (ed), The Amazon. Dodrecht, Springer-Verlag.

Rowe, C.L. 2000. Global distribution, phylogeny and taxonomy of the freshwater zooplankton genus Holopedium. MSc Thesis in Zoology. University of Guelph, Guelph. 323p.

Silva, A.M.A. da; Medeiros, P.R. de; Silva, M.C.B.C. and Barbosa, J.E.L. 2009. Diel vertical migration and distribution of zooplankton in a tropical Brazilian reservoir. Biotemas, 22(1): 49-57.

Smirnov, N.N. 1996. Cladocera: the Chydorinae and Sayciinae (Chydoridae) of the World. In: Dumont. H.J.F. (ed), Guides to the Identification of the Microinvertebrates of the Continental Waters of the World. Amsterdam: SPB Academic Publishing, 197p.

Sterza, J.M.; Suzuki, M.S. and Taouil, A. 2002. Resposta do zooplâncton a adição de nutrients inorgânicos ( $\mathrm{N}$ e $\mathrm{P})$ em mesocosmos na lagoa do Açu, Campos dos Goytacazes/São João da Barra, RJ. Acta Limnologica Brasiliensia, 14(2): 87-94.

Tollrian, R. and Dodson, S.I. 1999. Inducible defenses in Cladocera: constraints, costs and multipredator environments. p. 177-202. In: Tollrian, R and Harvell, C.D. (eds), The ecology and evolution of inducible defenses. Princeton, Princeton University Press.

Vandamme, K.; Chiambeng, J.; Maiphae, S. and Dumont, H.J. 2003. New species in the rheophilous genus Nicsmirnovius Chiambeng and Dumont, 1999 (Branchiopoda: Anomopoda: Chydoridae) and reassignment of Alona eximia Kiser, 1948 and Alonella fitzpatricki Chien, 1970. Hydrobiologia, 499: 25-49.

Velho, L.F.M.; Lansac-Tôha, F.A. and Bonecker, C.C. 2000. New record of planktonic cladoceran to the upper Paraná River, Brasil: Bosmina huaroensis Delachaux, 1918. Revista Brasileira de Biologia, 60(4): 633-636.

Wetzel, R.G. 1983. Limnology. 2a Ed. New York, CBS College Publishers, 767p.

Whiteside, M.C.; Willians, J.B. and White, P. 1978. Seasonal abundance and pattern of Chydorid Cladocera in mud and vegetative habitats. Ecology, 59(6): 1177-1188.

Zaret, T.M. 1972. Predator-Prey interaction in a tropical lacustrine ecosystem. Ecology, 53: 248-257.

Zaret, T.M. and Kerfoot, W.C. 1975. Fish predation on Bosmina longirostris: Body size selection versus visibility selection. Ecology, 56: 232-237.

Zaret, T.M. and Suffern, J.S. 1976. Vertical migration in zooplankton as a predator avoidance mechanism. Limnology and Oceanography, 21: 804-813.
Submitted 06 May 2011 Accepted 30 November 2011 